ZOOLOGIA 31 (3): 271-274, June, 2014

http://dx.doi.org/10.1590/S1984-46702014000300009

\title{
A new species of Neoseiulus (Acari: Mesostigmata: Phytoseiidae) with a key for the Brazilian species of the genus
}

\author{
Matheus dos Santos Rocha ${ }^{1,4}$, Guilherme Liberato da Silva ${ }^{2} \&$ Noeli Juarez Ferla ${ }^{3}$
}

\author{
'Laboratório de Diversidade e Sistemática de Arachnida, Programa de Pós-Graduação em Biologia, Universidade do Vale dos \\ Sinos. 93022-000 São Leopoldo, RS, Brasil. \\ 2 Departamento de Microbiologia, Imunologia e Parasitologia, Universidade Federal do Rio Grande do Sul. 90050-170 Porto \\ Alegre, RS, Brazil \\ ${ }^{3}$ Laboratório de Acarologia, Museu de Ciências Naturais, UNIVATES - Centro Universitário. 95900-000 Lajeado, RS, Brazil. \\ ${ }^{4}$ Corresponding author. E-mail: mrocha0602@gmail.com
}

\begin{abstract}
Neoseiulus Hughes, 1948 is currently one of the largest genus of Phytoseiidae Berlese. Neoseiulus demitei sp. nov., a new species of phytoseiid mite from Rio Grande do Sul State, Brazil, is illustrated and described based on specimens collected on Tibouchina sp. (Melastomataceae) plants. This new species differs from others by having most of propodossomal setae reaching the base of nearby setae and a constriction of ventrianal shield at level of preanal pores. Nevertheless, this new species is the first of the species subgroup kennetti described from Brazil. A key of Neoseiulus species reported in Brazil is also included.
\end{abstract}

KEY WORDS. Amblyseiinae; native environment; Neoseiulini; predator; Rio Grande do Sul.

Phytoseiidae (Acari: Mesostigmata) is a large family of predatory mites. They are fast-moving, active predators, feeding mostly on mites but also on small insects, nematodes and fungi, and may feed on plants, including pollen and extrafloral exudates. Owing to their success in spider control, Phytoseiids are the best known and most studied group of predatory mites (GERSON et al. 2003). The Amblyseiinae is the largest subfamily, with approximately 1,500 nominal species (CHANT \& MCMurTRY 2007). Species of Neoseiulus Hughes, 1948 have been commercially reared to be used as biological control agents of several species of thrips and other small pest insects and mites in Europe and North America over the past 20 years (BEARD 2001).

Neoseiulus includes 389 described species (Dемiтe et al. 2014) found in all zoogeographic regions, except Antarctica, in a wide variety habitats (CHANT \& McMurtry 2003). Twenty species of Neoseiulus have been reported from Brazil. Of these, eight had already been found to occur in the state of Rio Grande do Sul (Demite et al. 2014.

In this article, a new species of barkeri species group, Neoseiulus demitei sp. nov., is described and illustrated from specimens collected in the State of Rio Grande do Sul, Brazil. A key to Brazilian Neoseiulus species is also included.

\section{MATERIAL AND METHODS}

The mites were collected from leaves of Tibouchina sp. (Melastomataceae), observed under a binocular microscope, mounted on glass slides in Hoyer's medium and observed un- der a phase contrast microscope Leica ${ }^{\circledR}$ DM 750 . Drawings were made using a camera Lucida apparatus and the lines were highlighted using Corel Draw X5 ${ }^{\circledR}$.

The classification system used is that of CHANT \& MCMurTRY (2007). The setal nomenclature is that of Rowell et al. (1978) and Chant \& Yoshida-Shaul (1992) for the dorsal and ventral surfaces of the idiosoma, respectively. Measurements are given in micrometers $(\mu \mathrm{m})$, holotype measurements are shown in bold type followed by their mean and range within parentheses.

\section{TAXONOMY}

\section{Neoseiulus demitei sp.nov. \\ Figs 1-7}

Adult female $(\mathrm{n}=8)$. Idiosomal setal pattern (CHANT \& Yoshida-Shaul 1992): 10A:9B/JV-3:ZV. Dorsum (Fig. 1): dorsal shield smooth, with a few striae anterolaterally; 6 pairs of lyrifissures and 9 pairs of pores, 367363 (355-370) long and 227224 (215-230) wide. Setae j1 2929 (28-32), j3 4441 (38-44), j4 4339 (35-43), j5 2726 (24-27), j6 3834 (32-38), J2 3230 (2832), J5 1211 (10-12), z2 3434 (33-35), z4 5754 (50-59), z5 3331 (28-35), Z1 4442 (39-45), Z4 5551 (47-55), Z5 67 62 (57-67), s4 6663 (60-66), S2 4746 (43-50), S4 2323 (19-26), S5 2321 (1824), r3 5048 (45-50), R1 3130 (29-31). All setae smooth and sharp-tipped, except Z5 slightly serrate. Venter (Fig. 2): sternal shield smooth, with three pairs of setae and two pairs of lyrifissures, seta St 4 set on distinct metasternal shields; distances between St1-St3 6764 (61-67), St2-St2 6766 (65-67). Genital

2014 Sociedade Brasileira de Zoologia | www.sbzoologia.org.br | www.scielo.br/zool All content of the journal, except where identified, is licensed under a Creative Commons attribution-type BY-NC. 


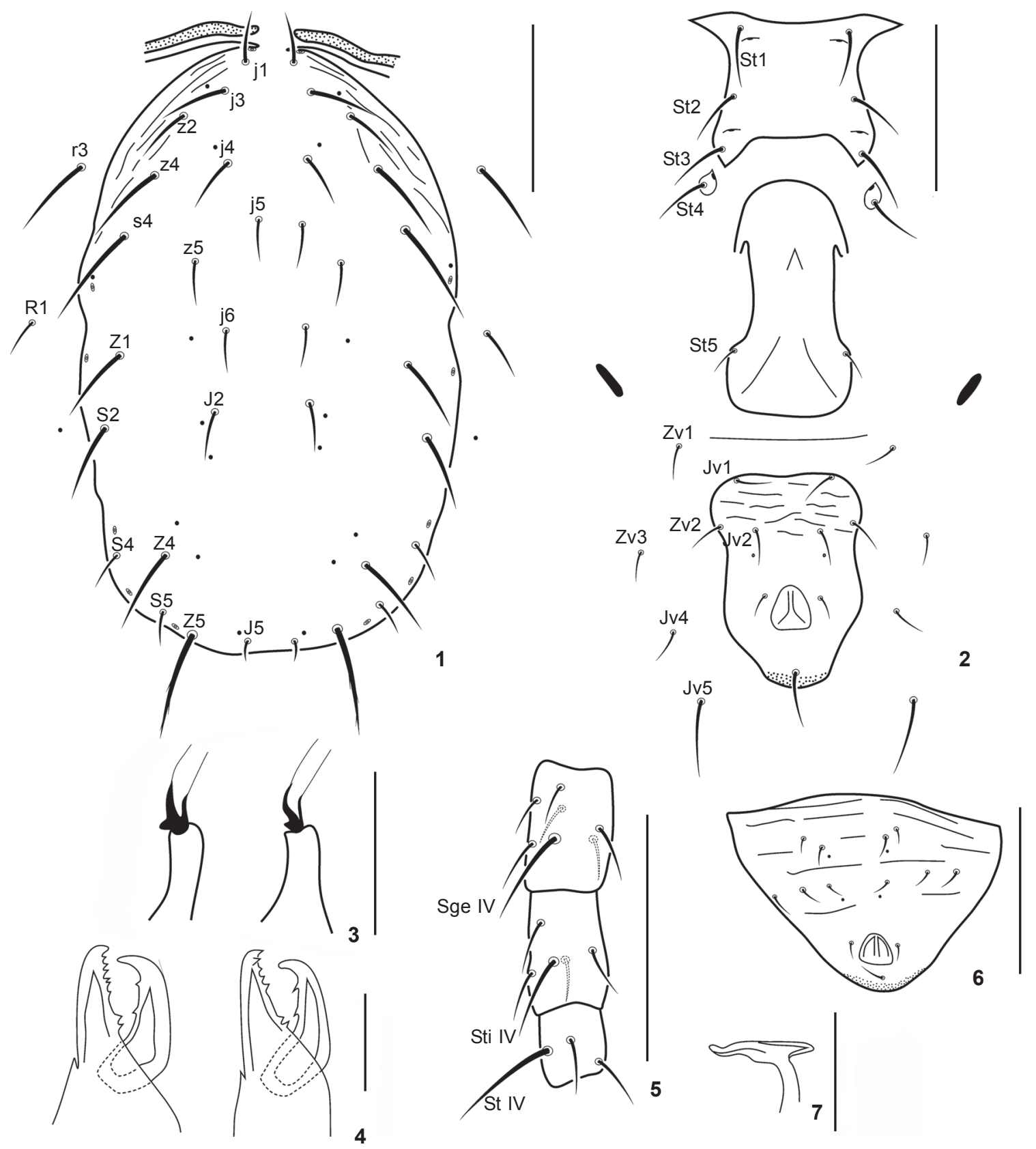

Figures 1-7. Neoseiulus demitei sp. nov. (1-5) Female: (1) dorsal shield; (2) ventral surface; (3) spermatheca; (4) chelicera; (5) leg IV: genu, tibia and basitarsus. (6-7) Male: (6) ventri-anal shield; (7) spermatodactyl. (j-J) Dorso-central setae, (JV) medial ventral setae, ( $r$ R) marginal setae, (Sge, Sti, St) setaceous macrosetae, (s-S) lateral setae, (ST) sternal setae, (ZV) mediolateral ventral setae, (z-Z) mediolateral setae. Scale bars: 1, 2, 5, $6=100 \mu \mathrm{m}, 3,4,7=20 \mu \mathrm{m}$.

shield smooth, distance between St5-St5 6360 (56-63). Ventrianal shield pentagonal, with light striations, $125126(120-$ 130) long, 9086 (80-91) wide at level of JV2 and 7979 (75-82) wide at level of anus, with three pairs of preanal setae (JV1, JV2, and ZV2) and pre-anal pores posterolateral of JV2. Four pairs of opisthogastric setae on unsclerotized cuticle (JV4, JV5, ZV1 and ZV3). Ventral setae smooth. With one pair of metapodal plates. Peritreme almost reaching level of $j 1$. Spermatheca (Fig. 3): ca- 
lyx saccular, 1615 (14-17) long, atrium narrower than base of calyx and bifurcate (invaginated) at junction with major duct. Chelicera (Fig. 4): Movable cheliceral digit 3029 (27-31) long, with 2 teeth; fixed cheliceral digit 2829 (28-30) long, with 6-8 teeth. Pilus dentilis not visible. Legs (Fig. 5): only the leg IV with setaceous macrosetae, with the following lengths: Sge IV 4541 (38-45), Sti IV 3231 (30-33), St IV 4747 (43-50).

Adult male $(\mathrm{n}=3)$. Dorsum: Dorsal shield pattern similar to female, 280292 (280-300) long and 155163 (155-170) wide. Setae j1 2021 (20-22), j3 30 30, j4 22 22, j5 2021 (20-22), j6 22 23 (22-25), J2 2223 (22-24), J5 1011 (10-13), z2 2525 (25-26), z4 3736 (35-37), z5 25 25, Z1 3535 (35-36), Z4 3736 (35-37), Z5 4041 (40-42), s4 5049 (48-50), S2 3231 (30-32), S4 2019 (17-22), S5 1515 (15-16), r3 3232 (30-33), R1 2526 (25-27). Venter (Fig. 6): sternogenital shield smooth. Ventrianal shield triangular, with a few striae, 120123 (120-125) long and 160 163 (160-163) wide at anterior corners, with five pairs of preanal setae, two pairs of small, rounded pores. Seta JV5 smooth. Peritreme almost reaching level of j1. Chelicera (Fig. 7): fixed digit 2223 (20-25) long and movable digit 2322 (21-24) long, spermatodactyl T-shaped, with shaft 2523 (22-25) long. Legs: only leg IV with setaceous macrosetae, follows lengths: Sge IV 3935 (30-39), Sti IV 2425 (24-26) and St IV 3737.

Type material. Holotype female, four paratypes female and paratype male, BraziL, Rio Grande do Sul: Forquetinha, from Tibouchina sp. (Melastomataceae), 06/XI/2012, deposited at the Departamento de Entomologia, Fitopatologia e Zoologia Agrícola (Agricultural Entomology, Phytopathology and Zoology Department), Escola Superior de Agricultura "Luiz de Queiroz" (ESALQ), Universidade de São Paulo (USP), Piracicaba, SP, Brazil. One paratype female, Brazil, Rio Grande do Sul Forquetinha, same collection data as holotype, deposited at Museum of Biological Diversity, the Ohio State University, 1315 Kinnear Road, Columbus, OH 432112, USA. Three paratype females, Brazil, Rio Grande do Sul, Forquetinha, same collection data as holotype, deposited at Museu de Ciências Naturais (ZAUMCN), UNIVATES - Centro Universitário, Lajeado, Rio Grande do Sul, Brazil.

Etymology. The new species was named in honor of Dr Peterson Demite, a Brazilian Acarologist.

Remarks. The studied specimens belong to Neoseiulus barkeri species group and share with the other species in it the spermatheca with atrium forked for at least half of its length until the juncture with major duct; and belongs to the kennetti species subgroup by having the atrium without vacuolated area at junction with major duct (CHANT \& McMurTRY 2003). The spermatheca of this new species resembles the spermathecae of Neoseiulus inflatus (Kuznetsov, 1984), Neoseiulus kennetti (Schuster \& Pritchard, 1963), Neoseiulus inornatus (SCHuster \& Pritchard, 1963), and Neoseiulus kodryensis (KoLodochKA, 1980). Neoseiulus inflatus differs from this new species by having macrosetae only on St IV, Seta Z5 serrated, five teeth on fixed digit and one tooth on movable digit; from N. kennetti by having dorsal shield reticulated, macrosetae only on Ge IV and St IV, peritreme extending to level of seta $j 3$, two teeth on fixed digit and without tooth on movable digit; from $N$. inornatus by having macrosetae only on Ge IV and St IV, setae Z4 and Z5 serrated and longer; N. kodryensis by having macrosetae St IV longer, setae Z4 and Z5 serrated and longer, three teeth on fixed digit and one tooth on movable digit. The new species differs from all species of the genus by having most propodossomal setae reaching the base of nearby setae and a constriction of ventrianal shield at level of preanal pores.

\section{Key for females of Neoseiulus species of Brazil (based on ChANt \& McMurtry 2003)}

1. Spermatheca with atrium forked for at least half its length at juncture with major duct, or atrium appearing thickwalled, vacuolated ................ barkeri species group ........2

1 '. Spermatheca with atrium not deeply forked at juncture with major duct, not appearing thick-walled, vacuolated ...... 6

2. Spermatheca with atrium narrower than base of calyx, calyx never basally constricted or stalked

kenetti species subgroup ........ 3

2 '. Spermatheca with atrium as wide as or wider than base of calyx, calyx sometimes basally constricted or stalked .... 4

3. Most anterolateral setae on dorsal shield shorter than the length between their setae nearby; Setae Z5 with $27 \mu \mathrm{m}$; ventrianal shield not constricted at level JV2; macrosetae absent on St IV .............. Neoseiulus gracilis (Muma, 1962)

3 '. Most anterolateral setae on dorsal shield longer than the length between their setae nearby; setae Z5 with $55 \mu \mathrm{m}$; ventrianal shield constricted at level JV2; macrosetae present on Sge IV, Sti IV and St IV ....

Neoseiulus demitei sp. nov.

4. Calyx not markedly constricted or stalked at junction with atrium; atrium deeply forked at juncture with major duct but without vacuolated area ... barkeri species subgroup..5

4 '. Calyx stalked or narrowly constricted at juncture with atrium; stalk sometimes short and blending into atrium or slender; atrium with vacuolated area ... womersleyi species subgroup ...... Neoseiulus neoaurescens (Moraes \& Mesa, 1988)

5. Setae Z5 serrated; peritreme not extending at level $\mathrm{j} 1$; macrosetae St IV $(68 \mu \mathrm{m})$ Neoseiulus barkeri Hughes, 1948

5'. Setae Z5 smooth; peritreme extending forward to $j 1$; macrosetae St IV $(58 \mu \mathrm{m})$

Neoseiulus transversus Denmark \& Muma, 1973

6 . Female ventrianal shield large, square or rectangular, rounded posteriorly $(\mathrm{L} / \mathrm{W}$ ratio $=1.0-1.3: 1.0)$; dorsal shield with marked shoulder at level of seta $\mathrm{r} 3$ paspalivorus species group ..........7

6 '. Female ventrianal shield pentagonal or with lateral margins slightly rounded; dorsal shield without marked shoulder at level of seta $\mathrm{r} 3$........... cucumeris species group .........10

7. Peritreme extending at level $\mathrm{j} 1$............................................ 8

7'. Peritreme extending at level j3 ...................................... 9 
8. Setae $\mathrm{r} 3$ shorter than R1; Setae Z5 serrated

Neoseiulus baraki Athias-Henriot

8'. Setae r3 longer than R1; Setae Z5 smooth Neoseiulus mumai (Denmark, 1965)

9. Fixed digit with seven teeth; macrosetae on St IV (29); fourth pair of sternal setae free on cuticle Neoseiulus benjamini (Schicha, 1981)

9'. Fixed digit with six teeth; macrosetae on St IV (15); fourth pair of sternal setae on metasternal plates

. Neoseiulus paspalivorus (De Leon, 1957)

10. Dorsal setae strongly barbed .........tunus species subgroup

$10^{\prime}$. Dorsal setae not strongly barbed .............cucumeris species subgroup ... 12

11. Only seta J5 smooth; macrosetae on leg IV setaceous; cervix of spermatheca fundibuliform

Neoseiulus neotunus (Denmark \& Muma, 1973)

11'. All j-J series smooth; macrosetae on leg IV are knobbed distally; cervix of spermatheca cup-shapedNeoseiulus tunus (De Leon, 1967)

12. Most setae on dorsal shield long (40-60), often much longer than bases of nearby setae. 13

12 '. Most setae on dorsal shield short, not reaching the bases of nearby setae 15

13. Only macrosetae on St IV 14

13'. Macrosetae on Sge IV, Sti IV and St IV 19

14. Cervix of spermatheca elongate; peritreme extending at level j1 .......... Neoseiulus anonymus (Chant \& Baker, 1965)

14 '. Cervix of spermatheca cup-shaped; peritreme extending at level j3 ........ Neoseiulus idaeus Denmark \& Muma, 1973

15. Only setae Z5 strongly serrated and stout .Neoseiulus veigai Gondim Jr. \& Moraes, 2001

$15^{\prime}$. Setae Z5 serrated or smooth, not stout 16

16. Setae Z5 smooth; cervix of spermatheca wider than long... Neoseiulus paraibensis (Moraes \& McMurtry, 1983)

16 '. Setae Z5 serrated; cervix of spermatheca longer than wide

17. Only setae Z5 serrated Neoseiulus californicus (McGregor, 1954)

$17^{\prime}$. Setae Z4 and Z5 serrated 18

18. Macrosetae on Sge IV, Sti IV and St IV; ventrianal shield not constriction at level setae JV2

Neoseiulus recifensis Gondim Jr \& Moraes, 2001

18'. Macrosetae only on St IV; ventrianal shield with constriction at level setae JV2

Neoseiulus melinis Lofego \& Moraes, 2003

19. All dorsal setae serrated except $\mathrm{j} 1$ and $\mathrm{j} 5$ smooth; J2 relatively longer, reaching the base of $\mathrm{Z} 4$

Neoseiulus pluridentatus Lofego \& Moraes, 2003

$19^{\prime}$. Only setae Z4 or Z5 serrated; J2 not reaching the base of Z4 20
20. Only setae Z5 serrated; cervix of spermatheca cup-shapped; macrosetae only on basitarsus IV and not knobbed ........... Neoseiulus fallacis (Garman, 1948)

20 '. Setae Z4 and Z5 serrated; cervix of spermatheca trumpetshaped; macrosetae present on genu, tibia and basitarsus IV and knobbed distally .... Neoseiulus barreti Kreiter, 2005

\section{ACKNOWLEDGEMENTS}

The authors thank Elisete M. de Freitas for plant identification; Gilberto J. de Moraes for technical support and for revising the manuscript, as well as anonymous referees for their constructive comments.

\section{LITERATURE CITED}

Athias-Henriot, C. 1957. Phytoseiidae et Aceosejidae (Acarina, Gamasina) d'Algerie. 1. Genres Blattisocius Keegan, Iphiseius Berlese, Amblyseius Berlese, Phytoseius Ribaga, Phytoseiulus Evans. Bulletin de la Société d'Histoire Naturelle de l'Afrique du Nord 48: 319-352.

BeARD, J.J. 2001. A review of Australian Neoseiulus Hughes and Typhlodromips de Leon (Acari: Phytoseiidae: Amblyseiinae). Invertebrate Taxonomy 15: 73-158.

Chant, D.A. \& J.A. Mcmurtry. 2003. A review of the subfamily Amblyseiinae Muma (Acari: Phytoseiidae). Part I. Neoseiulini new tribe. International Journal of Acarology 29 (1): 3-46.

Chant, D.A. \& J.A. Mcmurtry. 2007. Illustrated Keys and Diagnosis for the Genera and Subgenera of the Phytoseiidae of the World (Acari: Mesostigmata). Michigan, Indira Publishing House, 220p.

Chant, D.A. \& E. Yoshida-Shaul. 1992. Adult idiosomal setal patterns in the family Phytoseiidae (Acari: Gamasida). International Journal of Acarology 18: 177-193.

Demite, P.R.; G.J. De Moraes; J.A. Mcmurtry; H.A. Denmark \& R.C. Castilho. 2014. Phytoseiidae Database. Available online at: www.lea.esalq.usp.br/phytoseiidae [Accessed: 05/X/2013].

Denmark, H.A. \& M.H. Muma. 1973. Phytoseiid mites of Brazil (Acarina: Phytoseiidae). Revista Brasileira de Biologia 33: 235-276.

Denmark, H.A. 1965. Four new Phytoseiidae (Acari: Mesostigmata) from Florida. The Florida Entomologist 48: 89-95.

Gerson, U.; R.L Smiley \& R. OchoA. 2003. Mites (Acari) for pest control. Oxford, Blackwell Science, 539p.

Rowell, H.J.; D.A Chant \& R.I.C. Hansell. 1978. The determination of setal homologies and setal patterns on the dorsal shield in the family Phytoseiidae (Acarina: Mesostigmata). The Canadian Entomologist 110: 859-876.

Submitted: 03.X.2013; Accepted: 12.III.2014. Editorial responsibility: Antonio D. Brescovit 